\title{
A Conceptual Framework for IT Governance Mechanisms in Uganda's Higher Institutions of Learning
}

\author{
Lillian Ndagire, Kyambogo University, Uganda* \\ Gilbert Maiga, Makerere University, Kampala, Uganda \\ Benedict Oyo, Gulu University, Uganda
}

\begin{abstract}
Poor implementation of information technology governance (ITG) leads to several IT systems performing poorly, resulting in discontinuity of services, user frustration, loss of IT investment, increased redundancy, duplication of efforts, poor decision making, and reputation loss. In Uganda, implementation of ITG is low as many public sector organizations are yet to streamline. Yet, for higher institutions of learning (HILs), the implementation of ITG is unexplored. Therefore, this study sought to determine the required mechanisms to design an ITG framework for HILs in Uganda (IGHU). A descriptive field study was conducted, and the data were analyzed using SmartPLS 2.3.9 software. The causal relationships and validity of the constructs of IGHU were tested using partial least square path modeling. The coefficient of determination was 0.35 ; the path coefficient indicated both positive and negative relationships of independent to dependent constructs, and hypotheses such as accountability of IT projects and awareness campaigns were statistically significant.
\end{abstract}

\section{KEYWORDS}

Coefficient of Determination, Conceptual Framework, Higher Institutions of Learning, Hypothesis Tests, IT Governance, IT Governance Mechanisms, Path Coefficient, Structural Equation Modelling

\section{INTRODUCTION}

Today, several organizations rely on Information Technology (IT) for their daily operations and as a key driver for their economic growth (NITA-U, 2019), which has increased investment in IT systems (Adaba \& Rusu, 2014). Public sector organizations are among them. NITA-U (2018c) points that IT in public sector organizations improves effectiveness and efficiency in public service delivery. For Higher Institutions of Learning (HILs), IT enables automated access to public services using government IT platforms (Montenegro \& Flores, 2015). However, many IT systems do not perform as expected (Anjoga \& Kituyi, 2016), either failing at the inception stage or fail to meet desired objectives (Ali \& Nisar, 2016; Mayoka \& Kyeyune, 2012). Leading to discontinuity of services, user frustration, loss of IT investment, increased redundancy, duplication of efforts, poor decision-making, and reputation loss (Ali, 2018). Mohamed and Singh (2012) note that $67 \%$ of IT systems in public sector organizations of developing economies are challenged with justifying their investments. IT in 
HILs is complex, consisting of a heterogeneous set of technologies involving various applications, platforms, educational systems, and cloud applications to support their teaching, learning, research, and administrative processes (Bianchi et al., 2017a). Managing IT systems necessitates implementing Information Technology Governance (ITG) (Nyeko et al., 2018) to encourage and realize desirable behavior of IT use.

IT governance enables strategic alignment of IT to business objectives (Ali, 2018; Laita \& Belaissaoui, 2017), increases optimal use of IT resources while mitigating risks as a crucial element for the success and future for IT in organizations (Altemimi \& Zakaria, 2015). ITGI (2008) notes that globally $18 \%$ of companies have implemented ITG, $34 \%$ are in the process of implementing, and $24 \%$ are considering it. Furthermore, there is a $20 \%$ increase in profits for organizations with a high ITG implementation than those with poor performance adopting the same strategy (Weill \& Ross, 2004; Lunardi et al., 2014).

Despite the benefits of ITG, ITG implementation for public sector organizations of developing economies is still low (Niyonsenga \& Mwaulambo, 2018). Due to limited or no implementation of ITG mechanisms and frameworks (Adaba \& Rusu, 2014), difficulty in achieving institution-wide IT alignment with strategic business objectives (Gartlan \& Shanks, 2007); challenges in setting and measuring IT performance and contribution to business goals (De Haes et al., 2013); the complexity of IT systems (Bianchi \& Sousa, 2015), and lower managerial autonomy (Bojinov, 2017) where the limitation of IT staff to provide technical and administrative services lessens the role of IT management concepts in the general running of the educational institution.

Studies on ITG exist, such as Control Objectives for Information and related Technology (COBIT) which provides policies and good practices for IT security and control (ISACA, 2004). Information Technology Infrastructure Library (ITIL) describes managing IT services (Zhang et al., 2013). ITG for the public sector of developing countries (Laita \& Belaissaoui, 2017) provides mechanisms for implementing ITG in public sector organizations. A conceptual model for ITG in the public sector of developing countries (Tonelli et al., 2017) provides proportions and interconnection relations of IT governance. These studies point to frameworks that are generic, complex, expensive to implement, and time-consuming (Bianchi et al., 2017). Frameworks from these studies fail to address mechanisms to implement ITG in resource-constrained environments such as HILs in Uganda. Therefore, this study investigates the mechanisms for designing the conceptual framework to implement ITG in HILs in Uganda.

\section{IT Governance Mechanisms}

Weill and Ross (2004) state that ITG involves applying appropriate principles and practices to ensure that IT activities align with the organization's mission, strategy, and objectives. IT Governance Institute (ITGI) is universal association affianced in developing, implementing and use of worldwide recognized knowledge and practices of information system. Wiedenhoft et al. (2017) refer to ITG mechanisms as practices and arrangements in organizations responsible for meeting the goals and principles of ITG. Implementing ITG involves applying appropriate mechanisms that help make IT decisions and desirable use of IT (Nyeko et al., 2017). ITG can be implemented using a combination of structures, processes, and relational mechanisms (Bianchi et al., 2017).

Structures: Consist of organizational units, and roles and responsibilities for making IT decisions that enable fusion between business and IT management functions. In addition, ITG structures indicate the location of the IT department on the organogram (Adaba \& Rusu, 2014).

Processes: These are established formal organizational processes used to monitor and ensure that IT plans are aligned with business needs. They incorporate management techniques and procedures consistent with existing IT strategies and policies (Tonelli et al., 2017).

Relational Mechanisms: Involve participation and collaboration between organizational executives, IT, and business management. These ensure knowledge sharing throughout the organization to support business and IT strategies alignment (Bianchi et al., 2017). 
Figure 1. Example of ITG practices (De Haes \& Van Grembergen, 2008, p. 6)

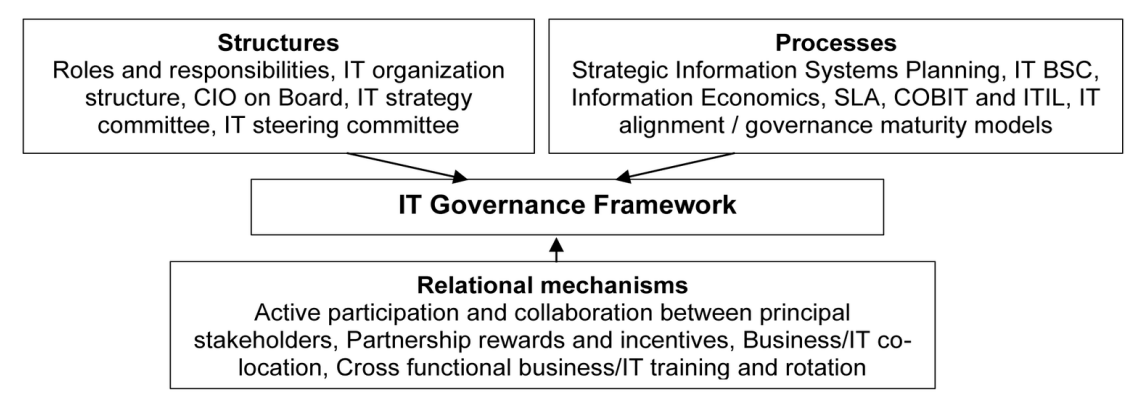

\section{Ugandan Context}

There is heavy investment in IT systems to support operations at Uganda's HILs. However, IT systems continue not to work to users' expectations. The different system types, structures, processes, and technology instituted in HILs contribute to the complexity and poor performance of IT systems (Anjoga \& Kituyi, 2015; NITA-U, 2019). A survey on IT performance for public sector organizations in Uganda indicated a low maturity level of ITG as many public sector organizations are yet to streamline ITG (NITA-U, 2018b), HILs inclusive. The survey indicated that: Information Communication and Technology (ICT) technical committee was at $29.9 \%$, the ICT steering committee was at $28.6 \%$, whereby $53.9 \%$ at unit-level and $33.9 \%$ at the department level. The high ITG practices at unit level and low at department level reveals senior managers' failure to fully understand the impact of IT in achieving the institution's goals which limits their support.

\section{RESEARCH METHODOLOGY}

\section{Sample Size}

Eight public degree awarding HILs were studied. The exploratory survey indicated 382 IT and business representatives, specifically directors/managers of IT and business and IT technicians. The sample size for the descriptive field study was based on the sample size determination table by (Bukhari, 2020). This defines the sample size required to represent a given population (Singh \& Masuku, 2014). Population size between 300 and 400 and confidence level of $95 \%$ (degree of accuracy/margin of error of 5\%) results in a sample size between 169 and 196. 272 questionnaires were circulated, and 181 were completed. Thus, 181 respondents were representative sample size for this study. The HILs were Makerere University, Mbarara University of Science and Technology, Gulu University, Kyambogo University, Busitema University, Kabale University, Lira University, and Soroti University.

\section{Research Process}

Data were collected using a questionnaire that consisted of a five Likert scale ranging from strongly agree to strongly disagree. The constructs of the questionnaire were based on the study of a baseline for ITG mechanisms (De Haes \& Van Grembergen, 2008) that provides mechanisms organizations can leverage to implement ITG in reality as in earlier studies (such as Ali, 2018; Nfuka, 2012) to derive the requirements for the conceptual framework (IGHU). Also, more mechanisms concerning the implementation of ITG for public sector organizations for developing economies were derived from the literature (see table 1).

Constructs for IGHU were compared with the existing studies for implementing ITG. The tick indicates the existing ITG mechanisms, while the $\mathrm{x}$ denotes the absence of ITG mechanisms. 
International Journal of Digital Strategy, Governance, and Business Transformation

Volume $11 \cdot$ Issue 1

Table 1. Comparison of existing studies of implementation of ITG

\begin{tabular}{|c|c|c|c|c|c|}
\hline \multirow[b]{2}{*}{$\begin{array}{c}\text { IT governance } \\
\text { mechanisms } \\
\text { (conceptual } \\
\text { framework) }\end{array}$} & \multicolumn{5}{|c|}{ Existing studies for implementing IT governance } \\
\hline & $\begin{array}{l}\text { COBIT } \\
4.1 \\
\text { (ISACA, } \\
2004)\end{array}$ & $\begin{array}{l}\text { ITIL } \\
\text { (Zhang } \\
\text { et al., } \\
2013 \text { ) }\end{array}$ & $\begin{array}{l}\text { National IT project } \\
\text { management } \\
\text { methodology V.3 } \\
(\text { NITA-U, 2013) }\end{array}$ & $\begin{array}{l}\text { The conceptual } \\
\text { model for IT } \\
\text { governance in } \\
\text { the public sector } \\
\text { (Janahi et al., } \\
\text { 2015) }\end{array}$ & $\begin{array}{l}\text { IT governance } \\
\text { conceptual } \\
\text { framework for public } \\
\text { sector (Laita \& } \\
\text { Belaissaoui, 2017) }\end{array}$ \\
\hline \multicolumn{6}{|c|}{ Internal Environment } \\
\hline \multicolumn{6}{|l|}{ Structures } \\
\hline $\begin{array}{l}\text { IT steering committee } \\
\text { (ISC) }\end{array}$ & $x$ & $x$ & $x$ & $x$ & $x$ \\
\hline $\begin{array}{l}\text { IT strategy committee } \\
\text { (IST) }\end{array}$ & $x$ & $\checkmark$ & $\checkmark$ & $x$ & $\checkmark$ \\
\hline $\mathrm{ClO}$ on board (CB) & $x$ & $x$ & $\checkmark$ & $x$ & $x$ \\
\hline $\begin{array}{l}\text { CIO reporting to CEO } \\
\text { (CRC) }\end{array}$ & $x$ & $x$ & $\mathrm{x}$ & $x$ & $x$ \\
\hline $\begin{array}{l}\text { Architecture steering } \\
\text { committee (ASC) }\end{array}$ & $x$ & $x$ & $\mathrm{x}$ & $x$ & $x$ \\
\hline \multicolumn{6}{|l|}{ Processes } \\
\hline $\begin{array}{l}\text { IT } \quad \text { performance } \\
\text { measurement (IPM) }\end{array}$ & $\checkmark$ & $\checkmark$ & $x$ & $\checkmark$ & $x$ \\
\hline $\begin{array}{l}\text { Service level } \\
\text { agreement (SLA) }\end{array}$ & $\checkmark$ & $\checkmark$ & $\mathrm{x}$ & $x$ & $\checkmark$ \\
\hline $\begin{array}{l}\text { IT } \quad \text { governance } \\
\text { frameworks - COBIT } \\
\text { and ITIL (IGF) }\end{array}$ & $\checkmark$ & $\checkmark$ & $x$ & $x$ & $\checkmark$ \\
\hline $\begin{array}{lr}\text { IT } & \text { governance } \\
\text { maturity } & \text { models } \\
\text { (IMM) } & \\
\end{array}$ & $x$ & $x$ & $x$ & $x$ & $x$ \\
\hline Monitoring (MN) & $\checkmark$ & $\checkmark$ & $x$ & $\checkmark$ & $\checkmark$ \\
\hline Accountability (AIP) & $x$ & $x$ & $x$ & $\checkmark$ & $x$ \\
\hline \multicolumn{6}{|l|}{ Relational Mechanisms } \\
\hline Training (TN) & $\checkmark$ & $x$ & $x$ & $x$ & $\checkmark$ \\
\hline $\begin{array}{l}\text { Involvement of senior } \\
\text { management (ISM) }\end{array}$ & $x$ & $x$ & $x$ & $\checkmark$ & $x$ \\
\hline IT leadership (IL) & $x$ & $x$ & $x$ & $x$ & \\
\hline $\begin{array}{l}\text { IT and business } \\
\text { partnership (IBP) }\end{array}$ & $x$ & $x$ & $x$ & $x$ & $\checkmark$ \\
\hline $\begin{array}{l}\text { Awareness campaign } \\
\text { (AC) }\end{array}$ & $x$ & $x$ & $x$ & $\checkmark$ & $x$ \\
\hline \multicolumn{6}{|c|}{ External Environment } \\
\hline Culture (CE) & $x$ & $\mathrm{x}$ & $x$ & $x$ & $\checkmark$ \\
\hline $\begin{array}{l}\text { Government, } \\
\text { Industry, and } \\
\text { Customers (GIC) }\end{array}$ & $x$ & $x$ & $x$ & $x$ & $\checkmark$ \\
\hline $\begin{array}{l}\text { Regulatory } \\
\text { requirements (RR) }\end{array}$ & $\mathrm{x}$ & $x$ & $\mathrm{x}$ & $x$ & $x$ \\
\hline $\begin{array}{l}\text { Stakeholders' } \\
\text { participation (SHP) }\end{array}$ & $\mathrm{x}$ & $x$ & $x$ & $x$ & $\checkmark$ \\
\hline
\end{tabular}

The comparison showed that the ITG conceptual framework for the public sector by Laita and Belaissaoui (2017) had the highest number of ITG mechanisms compared to other existing studies. Also, this framework consisted of external and internal environment mechanisms for implementing ITG and was designed for public sector organizations of developing countries. An internal environment shows established organizational structures that affect the overall strategic objectives and IT position (Ako-Nai \& Singh, 2019). Yet, it is also necessary for an organization to consider the external environment to obtain strategic goals. The external environment specifies IT-related dynamics outside the organization's direct control and board (Ako-Nai \& Singh, 2019). Scholars like Mohamed et al. (2012) and Ako-Nai and Singh (2019) show internal and external environments contributing to ITG implementation. Also, the institutional theory (Xue et al., 2008) offers ITG internal and external 
environments that contribute to organizations' decision-making. Thus, this study extended the ITG conceptual framework for the public sector by Laita and Belaissaoui (2017) to design IGHU.

\section{Reliability and Validity}

Composite reliability was used to measure internal consistency in scale items. Composite reliability gives actual score variance relative to the total scale score variance. Validity was tested using convergent validity that tests the degree to which two measures of constructs theoretically should be related are related (Taherdoost, 2016). To find convergent validity, the factor loading of the construct, composite reliability, and the average variance extracted have to be considered and the value ranges from 0 to 1 . The average variance extracted value should be above 0.50 for convergent validity to be accepted (Hair et al., 2016) (see table 2).

Discriminant validity refers to the extent to which the construct empirically differs from another construct (Hair et al., 2016). Discriminant validity was established using the Fornell-Lacker criterion by comparing the square root of the Average Variance Extracted (AVE) with the correlation of latent constructs (Hair et al., 2016) (see Table 4).

\section{Data Analysis}

Responses were coded into Ms. Excel, cleaned, and analyzed with SMARTPLS 2.9.2 software which is based on the partial least square method (PLS-PM) and designed for analyzing more intricate models (multivariate regression) (Rueda et al., 2017). The SMARTPLS that associates principal components analysis with ordinary least squares regressions, is a statistical tool that estimates multipart models and is viewed as a third generation multivariate data analysis simulation (Vanalle et al., 2017). PLSPM model assumes a causal relationship between the indicators and their constructs, and is used to test the causal relationships between the independent and dependent constructs.

\section{RESULTS}

\section{Demographics}

The study respondents were people who were most productive to provide information and key informants. Most of them were directors/managers of business (38\%) and the least were IT technicians (27\%), most of whom were male (69\%) and female were (31\%). Most respondents were aged 41-45 years $(29 \%)$ and the least were 55-60 years (1\%). In addition, majority had worked for 1-5 years $(52 \%)$ and the least had worked for 16-20 years (2\%). Further, most had masters (48\%) and the least had $\mathrm{PhD}(25 \%)$ degrees.

\section{Reliability and Validity}

The data from the questionnaire was sorted and entered in SmartPLS 3.2.9 computerized data analysis software. Results for composite reliability and AVE are in table 2.

Thirteen constructs met the acceptable level of composite reliability of 0.70 . Two constructs were above 0.9. They were; OS (1.00) and TN (1.00), indicating excellent reliability. One construct ranged between 0.80 and 0.90 . This was; ISM (0.83). Ten constructs ranged between 0.70 and 0.80 . However, ten constructs were below the acceptable level of 0.70. They were; AIP (0.67), CE (0.62), CRC (0.69), IBP (0.69), IGF (0.60), IMM (0.65), IPM (0.50), ISC (0.66), RR (0.62) and SHP (0.68).

Satisfactory convergent validity should be above 0.50 . Results in Table 2 showed that nineteen constructs met the AVE. Four constructs whose validity was below 0.50 were; CE (0.46), IPM (0.33), ISC (0.40) and RR (0.38).

Constructs whose composite reliability was below 0.70 and AVE was below 0.50 were discarded. They were; CE $(0.62,0.46)$, IPM $(0.50,0.33)$, ISC $(0.66,0.40)$ and RR $(0.62,0.38)$. 
Table 2. Composite reliability and AVE

\begin{tabular}{l|c|c|}
\hline \multicolumn{1}{|c|}{ Constructs } & Composite reliability & AVE \\
\hline AC & 0.71 & 0.53 \\
\hline AIP & 0.67 & 0.54 \\
\hline ASC & 0.72 & 0.53 \\
\hline CB & 0.71 & 0.55 \\
\hline CE & 0.62 & 0.46 \\
\hline CRC & 0.69 & 0.53 \\
\hline ITG & 0.77 & 0.63 \\
\hline GIC & 0.74 & 0.59 \\
\hline IBP & 0.69 & 0.53 \\
\hline IGF & 0.60 & 0.52 \\
\hline IL & 0.74 & 0.59 \\
\hline IMM & 0.65 & 0.55 \\
\hline IPM & 0.50 & 0.33 \\
\hline IRM & 0.73 & 0.51 \\
\hline ISC & 0.66 & 0.40 \\
\hline ISM & 0.83 & 0.71 \\
\hline IST & 0.71 & 0.55 \\
\hline MN & 0.73 & 1.00 \\
\hline OS & 1.00 & 0.38 \\
\hline RR & 0.62 & 0.55 \\
\hline SHP & 0.68 & 0.56 \\
\hline SLA & 0.71 & 1.00 \\
\hline TN & 1.00 & \\
\hline
\end{tabular}

\section{Factor Loadings}

The relationship of each item to the underlying construct was shown with factor loading. Factor loadings show how many items are loaded on their constructs. These are regression weights and show the relative importance of items, and the minimum acceptable value is 0.50 .

Maskey (2018) suggested retention of factor loadings above 0.50 . Henson and Roberts (2006) observed that it is unnecessary to keep all factors as they do not contribute much to the overall result. Hence, items that negatively affected their constructs were removed during analysis since they did not add value. Items whose factor loadings were below 0.50 were suppressed and not considered for IGHU. These were; AIP1 (0.41), IPM1 (0.04); IRM4 (0.02); IGF4 (0.21); RR2 (0.24); and SHP1 (0.45).

\section{Discriminant Validity}

Discriminant validity was used to determine if each construct loaded higher than any other construct it measured. Fornell-Larker criterion was used to assess discriminant validity.

Constructs loaded higher than the constructs they measured and were all above 0.5. Basing on the results, discriminant validity was achieved.

\section{Structural Equation Modeling}

This section presents the relationship of constructs used in IGHU. The coefficient of determination, path coefficient, and hypotheses tests are as follows.

\section{Coefficient of Determination $\left(\mathbf{R}^{2}\right)$}

$\mathrm{R}^{2}$ is the proportion of the total variability of the dependent variable that is accounted for by the regression equation in the independent variable. Figueiredo et al. (2011) note that $\mathrm{R}^{2}$ is between 0 and 1 , and a high $\mathrm{R}^{2}$ value indicates that the framework is good fit for the model. Latent constructs consist of exogenous and endogenous constructs. Figueiredo et al. (2011) point $\mathrm{R}^{2}$ values for endogenous 
Table 3. Factor loadings: outer loadings

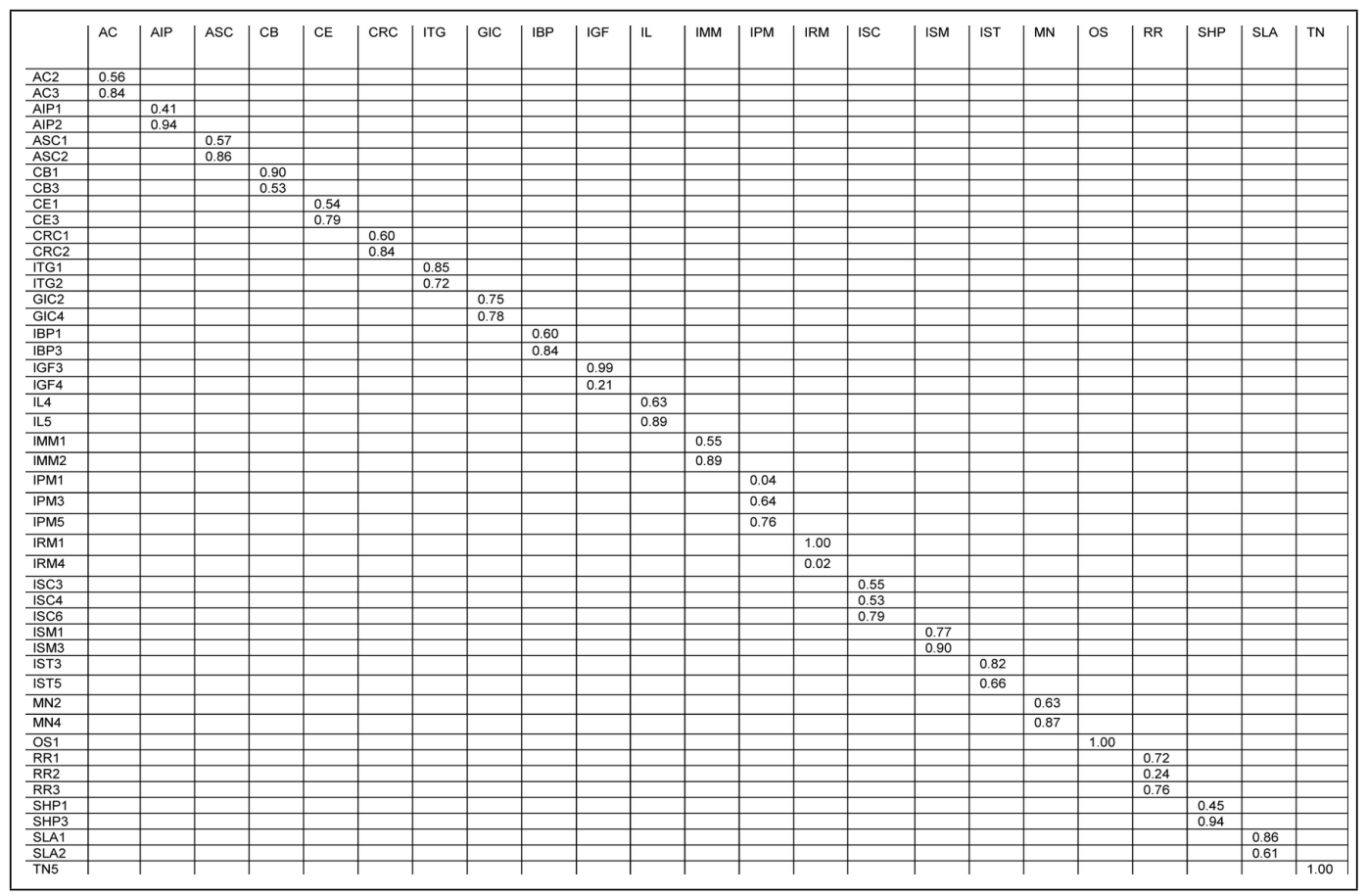

Table 4. Discriminant validity (Fornell-Larker criterion)

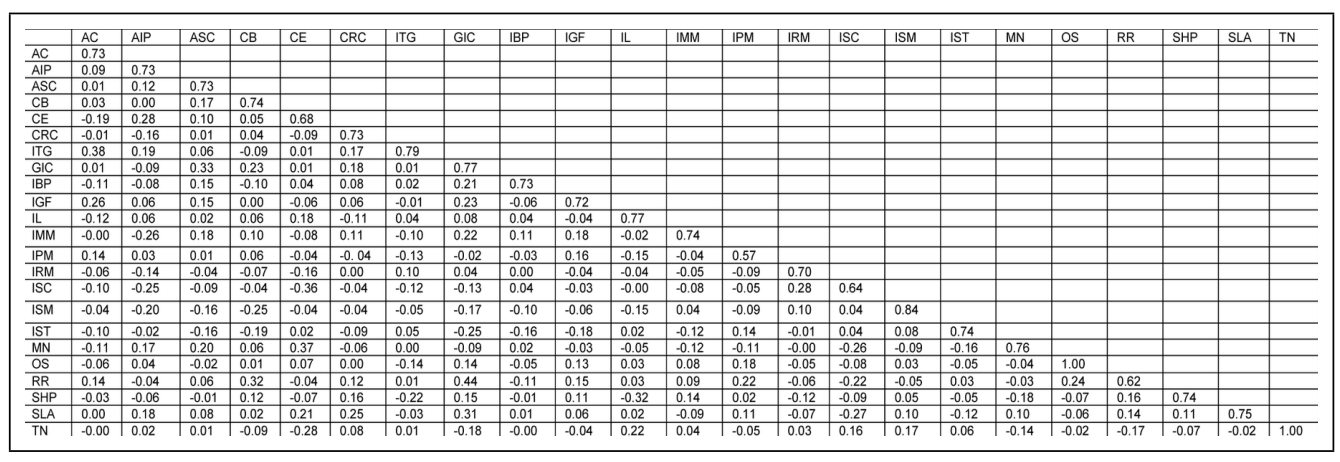

latent variables between $0.75-0.50$ as substantial, between $0.50-0.25$ as moderate, and below 0.25 as weak.

The $\mathrm{R}^{2}$ for ITG is $0.35(35 \%) . \mathrm{R}^{2}$ is reasonable since a moderate $\mathrm{R}^{2}$ should be between $0.50(50 \%)$ and $0.25(25 \%)$ for the endogenous latent construct.

\section{Path Coefficient}

Path coefficient $($ Beta $(\beta))$ is a form of multiple regression statistical analysis used to describe directed dependencies among given constructs. Hair et al. (2016) point $\beta$ value ranges between -1 and +1 , whereby -1 indicates a negative relationship and +1 shows a positive relationship. Path coefficient 
International Journal of Digital Strategy, Governance, and Business Transformation Volume $11 \cdot$ Issue 1

Figure 2. Coefficient of determination

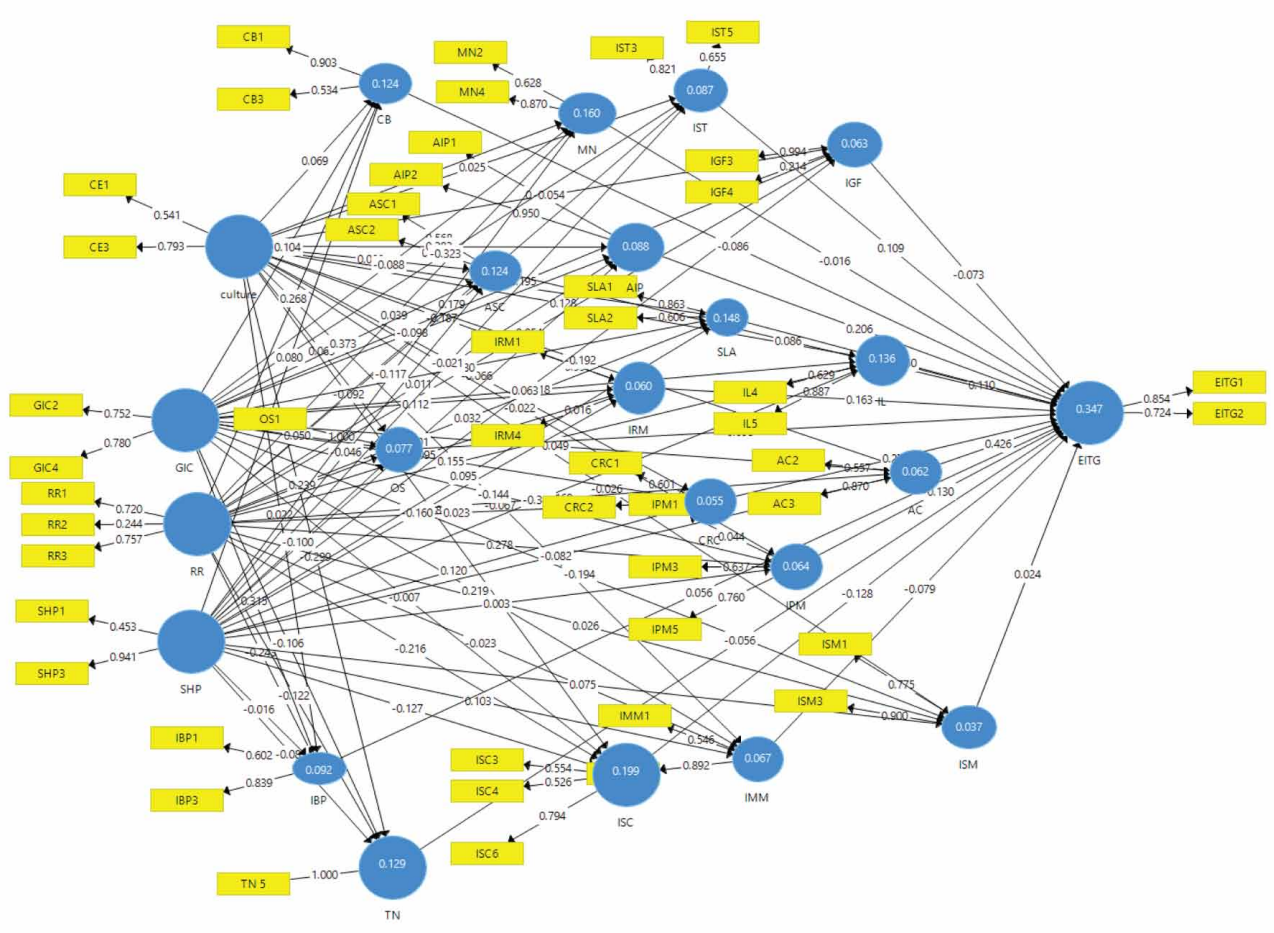

Table 5. Coefficient of determination

\begin{tabular}{|c|c|}
\hline Constructs & $\mathbf{R}^{2}$ \\
\hline AC & 0.06 \\
\hline AIP & 0.09 \\
\hline ASC & 0.12 \\
\hline CB & 0.12 \\
\hline IRC & 0.06 \\
\hline ITG & 0.35 \\
\hline IBP & 0.09 \\
\hline IGF & 0.06 \\
\hline IMM & 0.07 \\
\hline IL & 0.14 \\
\hline IRM & 0.06 \\
\hline ISM & 0.04 \\
\hline IST & 0.09 \\
\hline OS & 0.16 \\
\hline SLA & 0.08 \\
\hline TN & 0.15 \\
\hline & 0.13 \\
\hline
\end{tabular}


technique was done to find the correlation coefficients between external constructs and internal constructs. Also, between internal constructs and ITG. A path diagram was used to illustrate the path analysis of the constructs (see figure 3)

Both positive and negative path coefficients indicate the direct and indirect correlation between endogenous and exogenous constructs. This result is in line with previous scholars (Drikvand et al., 2011; Khayatnezhad et al., 2010) that reported both positive and negative correlations between constructs.

\section{Proposed Hypotheses}

The proposed hypotheses are as follows.

H1: Government, industry, and customers has a significant positive effect on the architecture steering committee for implementing ITG in HILs in Uganda.

H2: Stakeholders' participation has a significant positive effect on IT risk management for implementing ITG in HILs in Uganda.

H3: IT strategic committee has a significant positive effect on implementing ITG in HILs in Uganda.

$\mathrm{H} 4$ : CIO reporting to CEO has a significant positive effect on implementing ITG in HILs in Uganda.

H5: The architecture steering committee has a significant positive effect on implementing ITG in HILs in Uganda.

H6: Accountability for IT projects has a significant positive effect on implementing ITG in HILs in Uganda.

H7: IT risk management has a significant positive effect on implementing ITG in HILs in Uganda.

H8: IT leadership has a significant positive effect on implementing ITG in HILs in Uganda.

H9: IT/business partnerships has a significant positive effect on implementing ITG in HILs in Uganda.

H10: The involvement of senior management has a significant positive effect on implementing ITG in HILs in Uganda.

H11: Awareness campaigns have a significant positive effect on implementing ITG in HILs in Uganda.

Hypotheses were done using PLS-PM to test the statistical significance of the constructs of the conceptual framework. The confidence level was 95\% (degree of accuracy/margin of error of 5\%), and a p-value of $5 \%$ or $\mathrm{p}<0.05$ was used. Four hypotheses were statistically significant, while seven were statistically insignificant, as shown in table 7.

\section{The IGHU Conceptual Framework}

The conceptual framework consists of external and internal environment ITG mechanisms. The external environment mechanisms influence ITG through internal environment constructs. The internal environment mechanisms are further categorized as structures, processes, and relational mechanisms which constitute the ITG framework (Bianchi et al., 2017). The external environment consists of government, industry, and customers, and stakeholders' participation. Structure mechanisms are; IT strategy committee, $\mathrm{CIO}$ reporting to $\mathrm{CEO}$, and architecture steering committee. Process mechanisms are; accountability for IT projects and IT risk management. Relational mechanisms are; IT leadership, IT/business partnership, involvement of senior management, and awareness campaigns. The resultant conceptual framework for implementing ITG in HILs in Uganda is in figure 4.

\section{DISCUSSION OF RESULTS}

\section{Contribution of Theory to the IGHU Conceptual Framework}

The IGHU is based on a synthesis of IT governance mechanisms from IT governance conceptual framework for the public sector (Laita \& Belaissaoui, 2017), exploratory study into the design of an 
Figure 3. Path Coefficient $(\beta)$

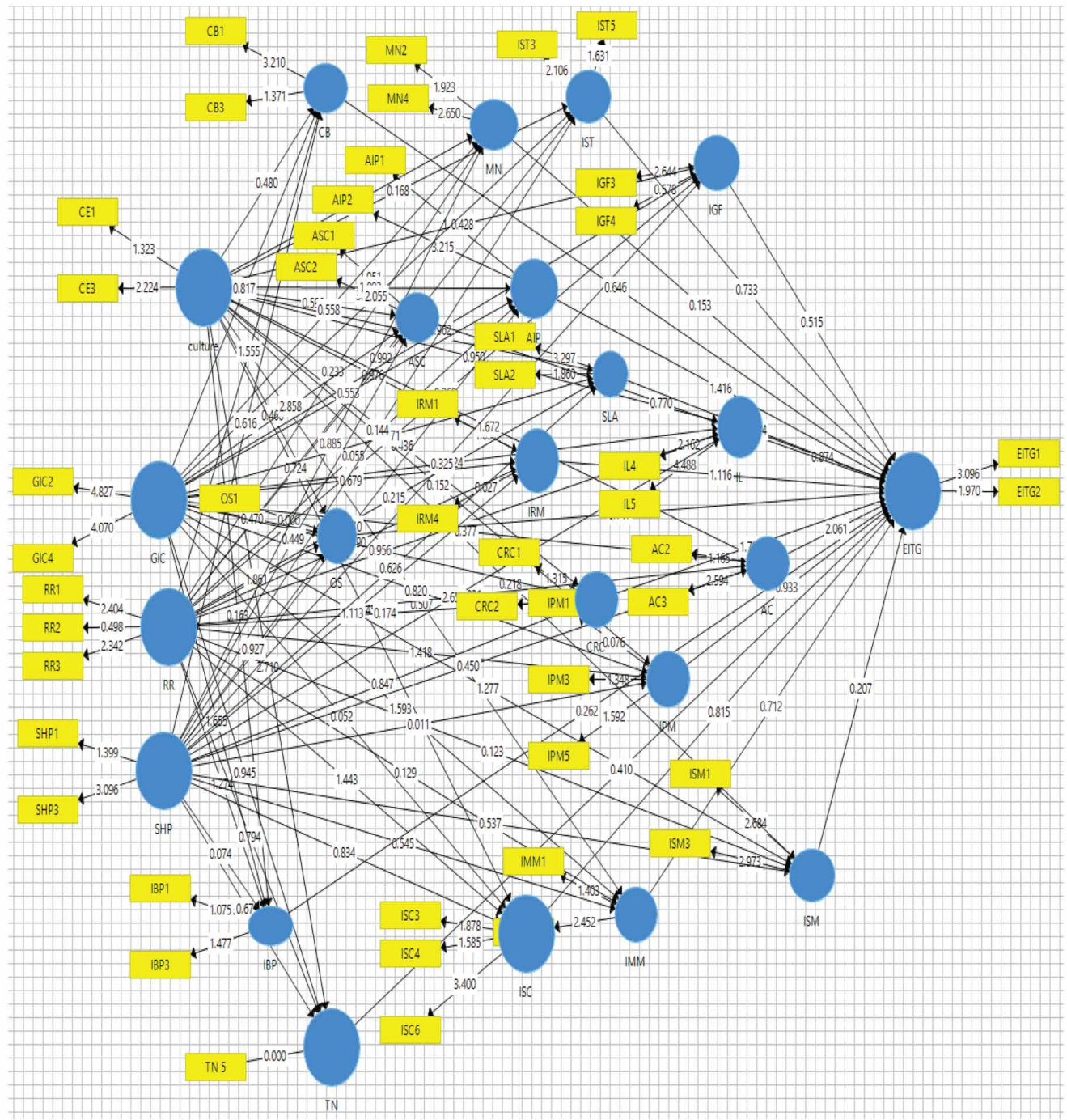

IT governance minimum baseline through Delphi research (De Haes \& Van Grembergen, 2008a), and a conceptual model for ITG in public sectors (Janahi et al., 2015). IGHU consists of two categories of ITG mechanisms: internal environment and external environment.

The external environment mechanisms extended from Laita and Belaissaoui (2017) were; Government, industry, and customers, and stakeholders' participation, while the internal environment mechanisms were; IT strategy committee, IT leadership, IT/business partnership. Accountability for IT Projects, IT risk management, involvement of senior management, and awareness campaigns were obtained from a conceptual model for IT governance in public sectors by Janahi et al. (2015). The architecture steering committee and CIO reporting to CEO were adopted from an exploratory study into the design of an IT governance minimum baseline through Delphi research by De Haes and Van Grembergen (2008a). 
Table 6. Path Coefficient ( $\beta)$

\begin{tabular}{|c|c|c|c|c|c|c|c|c|c|c|c|c|c|c|c|c|c|}
\hline & $A C$ & AIP & ASC & $\mathrm{CB}$ & CRC & ITG & IBP & IGF & IL & IMM & IRM & ISM & IST & MN & OS & SLA & TN \\
\hline$\overline{A C}$ & & & & & & 0.43 & & & & & & & & & & & \\
\hline AIP & & & & & & 0.21 & & & & & & & & & & & \\
\hline$\overline{A S C}$ & & & & & & 0.09 & & & & & & & & & & & \\
\hline $\mathrm{CB}$ & & & & & & -0.09 & & & & & & & & & & & \\
\hline CRC & & & & & & 0.27 & & & & & & & & & & & \\
\hline$\overline{G I C}$ & -0.05 & -0.10 & 0.37 & 0.10 & 0.15 & & 0.31 & 0.19 & 0.12 & 0.22 & 0.11 & -0.19 & -0.32 & -0.09 & 0.05 & 0.28 & -0.11 \\
\hline IBP & & & & & & 0.06 & & & & & & & & & & & \\
\hline IGF & & & & & & -0.07 & & & & & & & & & & & \\
\hline IL & & & & & & 0.11 & & & & & & & & & & & \\
\hline IMM & & & & & & -0.08 & & & & & & & & & & & \\
\hline IRM & & & & & & 0.16 & & & & & & & & & & & \\
\hline ISM & & & & & & 0.02 & & & & & & & & & & & \\
\hline$\overline{I S T}$ & & & & & & 0.11 & & & & & & & & & & & \\
\hline$\overline{\mathrm{MN}}$ & & & & & & -0.02 & & & & & & & & & & & \\
\hline$\overline{O S}$ & & & & & & -0.10 & & & & & & & & & & & \\
\hline$\overline{S H P}$ & -0.08 & 0.00 & -0.05 & 0.08 & 0.12 & & -0.02 & 0.06 & -0.32 & 0.10 & -0.16 & 0.08 & -0.02 & -0.12 & -0.10 & 0.10 & -0.08 \\
\hline$\overline{\text { SLA }}$ & & & & & & -0.15 & & & & & & & & & & & \\
\hline$\overline{T N}$ & & & & & & -0.06 & & & & & & & & & & & \\
\hline
\end{tabular}

Table 7. Hypotheses tests

\begin{tabular}{|l|l|c|c|c|c|l|} 
Hypotheses & Path & $\begin{array}{c}\text { Original } \\
\text { Sample }\end{array}$ & $\begin{array}{c}\text { Sample } \\
\text { Mean }\end{array}$ & $\begin{array}{c}\text { Standard } \\
\text { Deviation }\end{array}$ & $\begin{array}{c}\text { P-Value } \\
(\mathbf{P})\end{array}$ & $\begin{array}{c}\text { Significant } \\
\text { Test }\end{array}$ \\
\hline $\mathrm{H} 1$ & $\mathrm{GIC} \rightarrow$ ASC & 0.37 & 0.36 & 0.13 & 0.00 & Supported \\
\hline $\mathrm{H} 2$ & $\mathrm{SHP} \rightarrow$ IRM & 0.10 & 0.06 & 0.19 & 0.59 & Not supported \\
\hline $\mathrm{H} 3$ & $\mathrm{IST} \rightarrow$ ITG & 0.11 & 0.06 & 0.15 & 0.46 & Not supported \\
\hline $\mathrm{H} 4$ & $\mathrm{CRC}$ ITG & 0.27 & 0.23 & 0.15 & 0.03 & Supported \\
\hline $\mathrm{H} 5$ & $\mathrm{ASC} \rightarrow$ ITG & 0.09 & 0.07 & 0.11 & 0.44 & Not supported \\
\hline $\mathrm{H} 6$ & $\mathrm{AIP} \rightarrow$ ITG & 0.21 & 0.18 & 0.15 & 0.04 & Supported \\
\hline $\mathrm{H} 7$ & $\mathrm{IRM} \rightarrow$ ITG & 0.16 & 0.12 & 0.15 & 0.26 & Not supported \\
\hline $\mathrm{H} 8$ & $\mathrm{IL} \rightarrow$ ITG & 0.11 & 0.11 & 0.13 & 0.38 & Not supported \\
\hline $\mathrm{H} 9$ & $\mathrm{IBP} \rightarrow$ ITG & 0.06 & -0.00 & 0.21 & 0.79 & Not supported \\
\hline $\mathrm{H} 10$ & $\mathrm{ISM} \rightarrow$ ITG & 0.02 & 0.01 & 0.12 & 0.84 & Not supported \\
\hline
\end{tabular}

IGHU differs from Laita and Belaissaoui (2017) because of the additional internal environment mechanisms: awareness campaigns, accountability for IT projects, architecture steering committee, CIO reporting to CEO, IT risk management, and involvement of senior management in IT. IGHU differs from De Haes and Van Grembergen (2008a) because of the additional external environment and internal environment mechanisms: awareness campaigns, accountability for IT projects, IT risk management, and involvement of senior management in IT. IGHU differs from Janahi et al. (2015) by adding external environment and internal environment mechanisms such as architecture steering committee, CIO reporting to CEO, IT/business partnership, IT leadership, IT risk management, and IT strategy committee.

\section{Discussion of the Study Findings}

Hypotheses were tested for the constructs that had positive relationships with the dependent constructs. Four hypotheses were statistically significant, while seven were statistically insignificant. Quertemont (2011) notes that some constructs may be substantial, although they are not statistically significant. Schneider (2015) urges researchers to clarify why results with significant statistical tests 


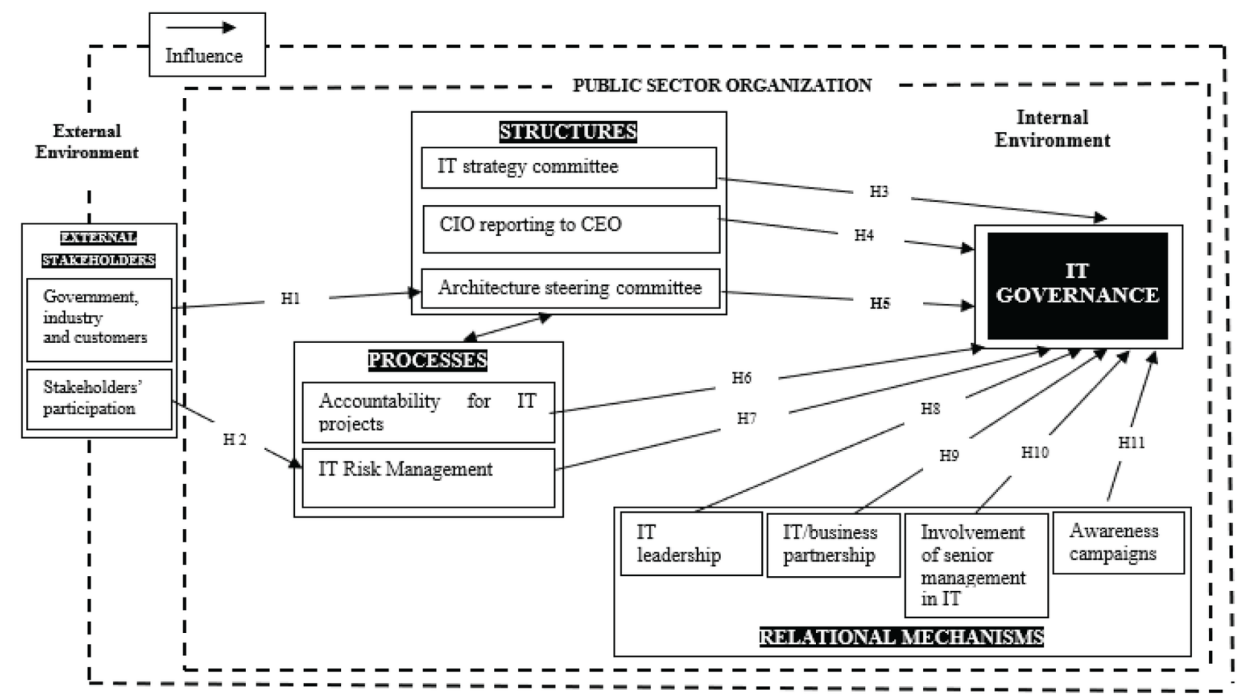

are insignificant in a given study. Scholars (such as Borja et al., 2018; Ali et al., 2009; Banker et al., 2011; Ferguson et al., 2013) have included statistically insignificant constructs in the developed framework. Therefore, both significant and insignificant constructs were considered for IGHU since they were assumed necessary for implementing ITG for HILs in Uganda. The discussion of findings is as follows.

IT strategy committee: The study did not find a significant influence. A possible explanation of insignificant results may be the confusion of the wording of IT strategy committee with the IT committee, commonly used in institutions. The study findings were inconsistent with prior literature that indicated IT strategy committee positively influences ITG (Ali \& Green, 2005). Also, there was a lack of dedicated IT strategy committees in HIL. This contends with Huff et al. (2004), who indicated a lack of board IT committees in organizations.

$\mathrm{CIO}$ reporting to the $\mathrm{VC}$ : The findings were consistent with prior literature that indicated $\mathrm{CIO}$ reporting structure is one of the decisions an organization should make because it involves the organization's highest IT executive, which affects its performance (Csaszar \& Clemons, 2006). Banker et al. (2011) support the direct reporting relationship of the CIO to the CEO because it helps the CIO promote a vision for IT, expose ideas of IT initiatives, and IT proposals are heard by the concerned executive who eventually facilitates the CIO's role.

IT risk management: Findings showed a significant negative influence of IT risk management on implementing ITG in HILs in Uganda. This was inconsistent with scholars (such as Alkhaldi et al., 2017; Lunardi et al., 2017) that indicated a significant relationship between risk management and ITG and also proposed risk management as a factor with the highest impact on ITG application where managers should ensure all essential roles in managing IT risks are well defined and staffed. The negative significance could be explained by the limited budget allocated to IT, and IT risks were noted to be handled as they came. The null findings may also be explained by existing standards insufficient to address IT risks (Jordan \& Musson, 2003).

IT leadership: In respect to IT leadership significantly influencing ITG implementation in HILs in Uganda, results showed a significant negative influence. Findings deviated from previous studies (Nfuka \& Rusu, 2013), indicating IT leadership management of business goals. It was revealed that IT leadership inspires, inñuences, and guides IT's strategic integration in an organization (De Haes \& 
Van Grembergen, 2008a). However, Nfuka and Rusu (2010) indicated a need to enhance IT leadership because of insufficient capacities and involvements in a setting whose IT knowledge and culture are not mature. This study revealed that HILs in Uganda recognized the importance of IT leadership and had all introduced IT directorates/departments.

IT/business partnerships: For IT/business partnerships that significantly influences ITG implementation in HILs in Uganda, findings showed a negative influence. This was inconsistent with previous literature (such as Lee et al., 2008) that widely investigated IT/business partnerships, including understanding and involvement in each other's requirements and initiatives to enhance value from IT. For example, Nfuka and Rusu (2010) reveal a leveled ground by IT and business people about IT prospects and business requirements as a path-way for ITG if lower awareness and broader coordination exist. A possible explanation for negative significance could be that many respondents were unfamiliar with the practice and indicated inadequate IT and business alignment that negatively affects ITG performance in situations requiring relational mechanisms.

Involvement of senior management in IT: The findings showed insignificant influence. This differed from several studies (such as Appleby, 2008). The null finding in this study may be explained by limited support by top managers in applying ITG, which is seen as a challenge. This is because IT's strategic importance is undervalued by the board of directors (Boritz \& Lim, 2007). The finding, however, is in line with one that found an insignificant effect of the committee on IT innovations (Héroux \& Fortin, 2016). Nolan and McFarlan (2005) note the boards' failure to fully understand IT impacts on the firm strategy and its role in measuring and monitoring IT.

Awareness and advocacy: In respect to awareness and advocacy significantly influencing ITG implementation in HILs in Uganda, the statistical results of this study were positive. This is consistent with Kambil and Lucas (2002) that suggested the sensitization of corporate management on technological trends and integration of IT with corporate strategy is the most crucial task of the board concerning IT. In this practice, engineers innovate and optimize IT capabilities and governance. A possible explanation for the positive influence is that workshops are usually held to sensitize stakeholders in HILs on new IT systems being introduced and refresher training for implemented IT systems.

\section{Contribution of the Study to Practice}

IGHU provides people in IT leadership and decision-making with appropriate mechanisms for implementing IT governance.

IGHU enables public managers and decision-makers to improve IT-related plans, prioritize limited IT resources for sustainability of public service delivery, and enhance the continuing strategies for the successful alignment of IT and business.

\section{Future Work}

Although this study provides mechanisms for implementing IT governance in the public sector of developing countries such as HILs in Uganda. Nevertheless, further research on the following is still required.

Institutions may align IT to business strategy to realize business objectives like improved efficiency and high return on investment. However, due to the fast changes in the business environment and technology, the expected goals may not be achieved; it may be difficult to anticipate such distractions when setting IT and business strategies. Thus, further research is required to investigate the challenges of IT alignment to business strategy for developing countries.

IT performance measurement is required since IT management is still a problem in the public sector of developing countries. Measuring IT performance enables IT/business planners to assess its optimal use while mitigating risks in such a resource-constrained environment. 


\section{CONCLUSION}

The study developed a conceptual framework for implementing ITG in HILs in Uganda (IGHU). A descriptive field study was conducted. The unit of analysis was IT and business representatives, and the unit of inquiry was IT and business directors/managers and IT technicians. Data were analyzed using Smart PLS 2.3.9 software. The constructs of IGHU were validated, and their relationships were tested using PLS-PM. $\mathrm{R}^{2}$ was moderate, the path coefficient had both positive and negative relationships of the independent to dependent constructs, and the hypotheses were statistically significant and insignificant. Thus, we can safely conclude that IGHU is well stipulated, accurate, and the constructs with their relationships are correct. Furthermore, the design of IGHU is complete since it consists of valid ITG mechanisms.

\section{REFERENCES}

Adaba, G. B., \& Rusu, L. (2014). IT Governance practices in a public organization in Ghana. International Journal of Innovation in the Digital Economy, 5(2), 14-23. doi:10.4018/ijide.2014040102

Ako-Nai, A., \& Singh, A. M. (2019). Information technology governance framework for improving organisational performance. South African Journal of Information Management, 21(1), 1-11. doi:10.4102/sajim.v21i1.1010 
Ali, A., \& Nisar, A. (2016). Exploration of IT Governance Practices and their Effect on Strategic Projects' Outcomes in Public Sector Organizations of Pakistan. International Journal of Computer Science and Network Security, 16, 10-19. http://paper.ijcsns.org/07_book/201608/20160802.pdf

Ali, S., Green, P., \& Parent, M. (2009). The role of a culture of compliance in information technology governance. GRCIS'09: Governance, Risk and Compliance, 459.

Ali. (2018). IT Governance Implementation Framework for Public Sector Organizations of Pakistan. University of Engineering \& Technology, Taxila. http://prr.hec.gov.pk/jspui/handle/123456789/11309

Alkhaldi, F. M., Hammami, S. M., \& Ahmar Uddin, M. (2017). Understanding value characteristics toward a robust IT governance application in private organizations using COBIT framework. International Journal of Engineering Business Management, 9, 9. doi:10.1177/1847979017703779

Altemimi, M., \& Zakaria, M. (2015). Developing Factors for Effective IT Governance Mechanism. Malaysian Software Engineering Conference, 245-251. doi:10.1109/MySEC.2015.7475228

Anjoga, H., \& Kituyi, G. M. (2015). A Framework for Usability of e-Government Services in Developing Countries. Academic Press.

Anjoga, H., Nyeko, S., \& Kituyi, G. M. (2014). A Framework for Usability of e-Government Services in Developing Countries. Electronic Journal of E-Government.

Appleby, C. (2008). IT \& the board: taking responsibility. Trustee, 61(2), 14-17.

Banker, R. D., Hu, N., Pavlou, P. A., \& Luftman, J. (2011). CIO reporting structure, strategic positioning, and firm performance. Management Information Systems Quarterly, 35(2), 487-504. doi:10.2307/23044053

Bianchi, I., Sousa, R., Pereira, R., \& Hillegersberg, J. (2017). Baseline mechanisms for IT governance at universities. Proceedings of the 25th European Conference on Information Systems (ECIS), 1551-1567.

Bianchi, I. S., \& Sousa, R. D. de. (2015). IT governance for public universities: Developing a model. Academic Press.

Bojinov, B. V. (2017). Problems IT Management in Universities. Academic Press.

Boritz, E., \& Lim, J. H. (2007). Impact of top management's IT knowledge and IT governance mechanisms on financial performance. ICIS 2007 Proceedings, 88.

Borja, S., Keungoui, K., \& Hyenyoung, Y. (2018). IT governance effectiveness and its influence on innovation product and process. Academic Press.

Bukhari, S. A. R. (2020). Bukhari Sample Size Calculator. Research Gate GMBH. doi:10.13140/ RG.2.2.27730.58563

Csaszar, F., \& Clemons, E. K. (2006). Governance of the IT Function: Valuing Agility and Quality of Training, Cooperation and Communications. In Proceedings of the 39th Hawaii International Conference on System Sciences. Los Alamitos, CA: IEEE Computer Society Press. doi:10.1109/HICSS.2006.197

De Haes, S., \& Van Grembergen, W. (2008). An exploratory study into the design of an IT governance minimum baseline through Delphi research. Communications of the Association for Information Systems, 22(1), 24. doi:10.17705/1CAIS.02224

De Haes, S., Van Grembergen, W., \& Debreceny, R. S. (2013). COBIT 5 and enterprise governance of information technology: Building blocks and research opportunities. Journal of Information Systems, 27(1), 307-324. doi:10.2308/isys-50422

Drikvand, R., Samiei, K., \& Hossinpor, T. (2011). Path coefficient analysis in hull-less barley under rainfed condition. Australian Journal of Basic and Applied Sciences, 5(12), 277-279.

Ferguson, C., Green, P., Vaswani, R., \& Wu, G. (2013). Determinants of effective information technology governance. International Journal of Auditing, 17(1), 75-99. doi:10.1111/j.1099-1123.2012.00458.x

Figueiredo, F. D. B., Júnior, J. A. S., \& Rocha, E. C. (2011). What is R2 all about? Leviathan (São Paulo), 3(3), 60-68. doi:10.11606/issn.2237-4485.lev.2011.132282 
Gartlan, J., \& Shanks, G. (2007). The alignment of business and information technology strategy in Australia. AJIS. Australasian Journal of Information Systems, 14(2). Advance online publication. doi:10.3127/ajis.v14i2.184

Hair, J. F., Hult, G. T. M., Ringle, C., \& Sarstedt, M. (2016). A primer on partial least squares structural equation modeling (PLS-SEM). Sage Publications.

Héroux, S., \& Fortin, A. (2016). The Influence of IT Governance, IT Competence and IT-Business Alignment on Innovation. Cahier de Recherche, 4.

Huff, S. L., Maher, M. P., \& Munro, M. C. (2004). What boards don't do - but must do - about information technology. Ivey Business Journal, 69(1), 1-4.

ISACA. (2004). COBIT Student Book. IT Governance Institute.

ITGI. (2008). IT Governance global status report. IT Governance Institute.

Janahi, L., Griffiths, M., \& Al-Ammal, H. (2015). A conceptual model for IT governance in public sectors. 2015 Fourth International Conference on Future Generation Communication Technology (FGCT), 1-9. doi:10.1109/ FGCT.2015.7300242

Jordan, E., \& Musson, D. (2003). The board view of electronic business risk. Proceedings of the 16th Bled ECommerce Conference - e Transformation, 819-830.

Kambil, A., \& Lucas, H. C. J. (2002). The board of directors and the management of information technology. Communications of the AIS, 8, 380-391. doi:10.17705/1CAIS.00826

Khayatnezhad, M., Zaefizadeh, M., Gholamin, R., \& Jamaati-e-Somarin, S. (2010). Study of genetic diversity and path analysis for yield in durum wheat genotypes under water and dry conditions. World Applied Sciences Journal, 9(6), 655-665.

Laita, A., \& Belaissaoui, M. (2017). Information technology governance in public sector organizations. Europe and MENA Cooperation Advances in Information and Communication Technologies, 331-340.

Lee, S. M., Kim, K., Paulson, P., \& Park, H. (2008). Developing a socio-technical framework for business-IT alignment. Industrial Management \& Data Systems, 108(9), 1167-1181.

Lowry, P., Zhang, J., Wang, C., \& Siponen, M. (2016). Why do adults engage in cyber bullying on social media? An integration of online disinhibition and deindividuation effects with the social structure and social learning model. Information Systems Research, 27(4), 962-986. doi:10.1287/isre.2016.0671

Lunardi, G. L., Becker, J. L., Maçada, A. C. G., \& Dolci, P. C. (2014). The impact of adopting IT governance on financial performance. A impirical analysis among Brazilian firms. International Journal of Accounting Information Systems, 15(1), 66-81. doi:10.1016/j.accinf.2013.02.001

Lunardi, G. L., Maçada, A. C. G., Becker, J. L., \& Van Grembergen, W. (2017). Antecedents of IT governance effectiveness: An empirical examination in Brazilian firms. Journal of Information Systems, 31(1), 41-57. doi:10.2308/isys-51626

Mayoka, K., \& Kyeyune, R. (2012). An Analysis of E-learning Information System Adoption in Ugandan Universities: Case of Makerere University Business School. Information Technology Research Journal, 2(1), 1-7.

Mohamed, N., \& Singh, G. (2012). A conceptual framework for information technology governance effectiveness in private organisations. Journal of Information Management \& Computer Security, 20(2), 88-106. doi: $10.1108 / 09685221211235616$

Montenegro, C. W., \& Flores, D. A. (2015). An integrated model for ICT governance and management applied to the council for evaluation, accreditation and quality assurance of higher education institutions in Ecuador (CEAACES). 2015 International Conference on Computing, Communication and Security(ICCCS), 1-9. doi:10.1109/CCCS.2015.7374158

Nfuka, E. N. (2012). IT Governance in Tanzanian public sector organizations. Stockholm University.

Nfuka, E. N., \& Rusu, L. (2010). IT governance maturity in the public sector organizations in a developing country: The case of Tanzania. Proceedings of the Sixteenth Americas Conference on Information Systems, 1-12. 
Nfuka, E. N., \& Rusu, L. (2013). Critical Success Framework for Implementing Effective IT Governance in Tanzanian Public Sector Organizations. Journal of Global Information Technology Management, 16(3), 53-77. doi:10.1080/1097198X.2013.10845642

NITA-U. (2018a). National Information Technology Survey 2017/18 Report. https://www.nita.go.ug/sites/default/ files/publications/National IT Survey April 10th.pdf

NITA-U. (2018b). NITA-U Strategic Plan 2018/19 - 2022/23. Author.

NITA-U. (2019). NITA-U Establishment. Author.

Niyonsenga, T., \& Mwaulambo, C. (2018). IT Governance Practices: A Multiple Case Study of Tanzanian Public Government Organisations. Jonkoping University.

Nolan, R., \& McFarlan, F. W. (2005). Information technology and the board of directors. Harvard Business Review, 83(10), 96-106. PMID:16250628

Nyeko. (2017). Determinants of Electronic Learning Adoption in Higher Institutions of Learning in Uganda: A Learners' Perspective. Information \& Technology Global Journal of Computer Science and Technology: H, 1(1).

Nyeko, S., Niwe, M., Moya, M., \& Kituyi, G. (2018). IT Governance Steering Committee, IT Competence and IT Governance Performance in Ugandan Public Universities. In 2018 IST-Africa Week Conference (IST-Africa). IEEE.

Quertemont, E. (2011). How to statistically show the absence of an effect. Psychologica Belgica, 51(2), 109-127. doi:10.5334/pb-51-2-109

Rueda, L., Benitez, J., \& Braojos, J. (2017). From traditional education technologies to student satisfaction in Management education: A theory of the role of social media applications. Information \& Management, 54(8), 1059-1071. doi:10.1016/j.im.2017.06.002

Singh, A. S., \& Masuku, M. B. (2014). Sampling techniques \& determination of sample size in applied statistics research: An overview. International Journal of Economics. Commerce and Management, 2(11), 1-22.

Taherdoost, H. (2016). Validity and reliability of the research instrument; how to test the validation of a questionnaire/survey in a research. International Journal of Academic Research in Management, 5(3), 28-36. doi:10.2139/ssrn.3205040

Tonelli, A. O., de Souza Bermejo, P. H., Dos Santos, P. A., Zuppo, L., \& Zambalde, A. L. (2017). It governance in the public sector: A conceptual model. Information Systems Frontiers, 19(3), 593-610. doi:10.1007/s10796015-9614-x

Vanalle, R. M., Ganga, G. M. D., Godinho Filho, M., \& Lucato, W. C. (2017). Green supply chain management: An investigation of pressures, practices, and performance within the Brazilian automotive supply chain. Journal of Cleaner Production, 151, 250-259. doi:10.1016/j.jclepro.2017.03.066

Weill, P., \& Ross, J. (2004). IT Governance: How Top Performers Manage IT Decision Rights for Superior Results. Harvard Business Press.

Wiedenhoft, C., Luciano, M., \& Magnagnagno, A. (2017). Information Technology governance in public organisations: Identifying mechanisms that meet its goals while respecting principles. JISTEM-Journal of Information Systems and Technology Management, 14(1), 69-87. doi:10.4301/S1807-17752017000100004

Xue, Y., Liang, H., \& Boulton, W. R. (2008). Information technology governance in information technology investment decision processes: The impact of investment characteristics, external environment, and internal context. Management Information Systems Quarterly, 32(1), 67-96. doi:10.2307/25148829

Zhang, Y., Zhang, J., \& Chen, J. (2013). Critical success factors in IT service management implementation: People, process, and technology perspectives. 2013 International Conference on Service Sciences (ICSS), 64-68. 
Ndagire Lillian is an Assistant Lecturer in the Department of Networks, School of Computing and Library Science, Kyambogo University. She is pursuing a PhD in Information Systems in the College of Computing and Information Sciences at Makerere University. The research area is IT governance for public sector organizations of developing countries. She holds a Masters of Information Technology from Makerere University and a Bachelor of Science (Computer Science \& Economics). Areas of specialization are database management, operating systems implementation, network configuration, systems analysis, and design. Lillian participates in several activities such as curriculum development for several IT-related programs and supervises research students, both undergraduates and postgraduates.

Gilbert Maiga $(P h D)$ is the current Dean of the School of Computing and informatics Technology at Makerere University's College of Computing and Information Sciences. He is an Associate Professor in the Department of Information Technology where he has mentored several Graduate Students researches to completion in the broad field of Information systems. He is also a former chair of the department of Information Technology at Makerere University. He has more than 15 years of teaching and research experience. His main areas of interest for research over are in: Information Systems evaluation, e-services (e-health and e-Governance) systems development and adoption. He has also published work on the use of Ontologies for biomedical data Integration.

Benedict Oyo holds a PhD in Information Systems. He is the current Dean, Faculty of Science at Gulu University. Benedict's current research focuses on the role of ICT innovations in development. This is reflected by three main areas: Implementation of MOOCs in low bandwidth environments; Application of crowdsourcing in open courseware development; Application of System Dynamics in modelling agricultural, health and livelihood systems; Benedict has led several systems development at Gulu University, including: Graduate Tracking System, Publication System, Covid-19 registration and attendance tracking system, Human Resource Management System, and an offline eLearning system. Benedict was in 2017 appointed to the 10-member board of the National ICT Initiatives Support Programme (NIISP) under the Ministry of ICT\&NG. Benedict serves on nine journal committees as an external reviewer, and has published over 15 peer reviewed articles since his PhD graduation in 2012. 